\title{
PERANCANGAN REBRANDING LOGO TERI BAJAK UNTUK PROMOSI OLEH-OLEH KHAS MEDAN
}

\author{
Siti Indah Lestari ${ }^{1}$, Rasmida ${ }^{2}$, Syafwandi $^{3}$ \\ ${ }^{1}$ Pascasarjana Institut Seni Indonesia Padangpanjang \\ ${ }^{2}$ Institut Seni Indonesia Padangpanjang \\ ${ }^{3}$ Universitas Negeri Padang \\ indah.ayangjelek@gmail.com
}

\begin{abstract}
ABSTRAK
Penelitian ini bertujuan membuat perancangan desain ulang untuk logo teri bajak Medan. Teri Bajak medan merupakan makanan berbahan dasar teri yang telah ada sejak tahun 2013 yang terjaga kualitas dan cita rasanya sampai saat ini, sebagai oleh-oleh yang khas di Kota Medan teri bajak sendiri memiliki rangkaian rasa pedas yang sangat khas. Teri bajak ini kurang di kenal masyarakat, hal ini dapat diketahui dari sedikitnya jumlah pengunjung, sebab yang mungkin terjadi adalah belum banyaknya masyarakat yang tidak tahu serta belum adanya identitas yang jelas seperti logo yang sesuai dengan keberadaan teri bajak sebagai oleh-oleh khas Kota Medan untuk menarik wisatawan yang berkunjung ke Kota Medan serta semakin banyaknya oleh-oleh khas Medan yang berkembang seperti cake dan lain-lain yang diolah public figure yang membuat daya beli teri bajak semakin menurun, dengan itu dilakukan rebranding logo yang mencirikan Kota Medan sebagai strategi untuk menarik pelanggan dan wisatawan yang berkunjung ke Kota Medan. Metode yang digunakan dalam penelitian ini adalah metode kualitatif serta analisis SWOT sebagai metode untuk menganalisis data. Diharap dengan adanya identitas yang jelas dapat mendorong keinginan masyarakat dan wisatawan untuk berkunjung.
\end{abstract}

Kata Kunci : Rebranding Logo, Teri Bajak, Keputusan Kunjungan

\begin{abstract}
This research aims to make a redesign design for Teri Bajak Medan logo. Teri Bajak medan is an anchovy-based food that has been around since 2013, which has maintained its quality and taste to date, as a typical souvenir in Medan plot town itself has a very distinctive spicy flavor series. Teri Bajak is less known by the public, this can be known from the small number of visitors, because that may happen is not many people who do not know and there is no clear identity such as the logo in accordance with the existence of anchovy as a typical gift by the City of Medan to attracting tourists who visit the city of Medan as well as the increasing number of typical Medan souvenirs that develop such as cake and others are processed public figures that make purchasing power plows decrease, with a rebranding logo that characterizes the city of Medan as a strategy to attract customers and tourists visiting the city of Medan. The method used in this study is a qualitative method and SWOT analysis as a method for analyzing data. It is hoped that with a clear identity can encourage the desire of the people and tourists to visit.
\end{abstract}

Keyword: Rebranding Logo, Teri Bajak, Decision to Visit 


\section{PENDAHULUAN}

\section{A. Latar Belakang}

Di era globalisasi saat ini, sektor pariwisata akan menjadi pendorong utama perekonomian dan menjadi industri yang mengglobal. Pariwisata akan memberikan banyak pemasukan bagi daerah yang sadar akan potensinya terhadap sektor pariwisata. Sektor pariwisata merupakan kegiatan yang tak pernah mati dan menjadi hal yang sangat penting bagi suatu negara. Dengan berkembangnya pariwisata akan mendongkrak sektor yang lain seperti: kunjungan wisatawan, ekonomi kreatif, membuka kesempatan kerja dan mengurangi pengangguran. Hal tersebut tidak terlepas dari peranan sektor ekonomi masyarakat yang terus berkembang seperti pengolahan produk-produk asli daerah yang dikemas apik menjadi oleholeh.

Teri Bajak merupakan makanan olahan asli daerah yangberbahan dasar teri yang di sajikan dengan berbagai varian sambal teri, seperti: teri kacang sambal merah/rawit, teri belah sambel merah/rawit, teri belah kacang sambal merah/rawit, kue bawang teri dan lain-lain. Teri yang diolah merupakan teri asli medan yang diambil dari laut sumatera utara, sebagai makanan khas medan, teri dibuat dengan banyak jenis makanan dan dikemas secara apik sebagai oleh-oleh khas Kota Medan.

Tetap semakin trennya oleh-oleh berbahan dasar kue di kota medan yang dikelola oleh public figure, semakin tergeser pula oleh-oleh khas lokal yang dijalani pemilik toko oleh-oleh Teri Bajak Medan.

Ketatnya persaingan membuat teri bajak medan sulit mematok harga yang tinggi, padahal harga bahan terus naik dari waktu ke waktu. Hal tersebut bertolak belakang dengan kenyataan bahwa teri bajak telah lama berkecimpung di pasar tersebut.

Melihat kondisi yang demikian, faktor-faktor tersebut di atas kemudian dianalisis dan di jadikan strategi sebagai upaya peningkatan citra 'Teri Bajak' sebagai oleh-oleh khas lokal Kota Medan.

Dari beberapa penjelasan di atas maka penulis akan membuat perancangan kembali logo 'Teri Bajak' sebagai oleh-oleh khas lokal medan yang mencirikan kota asalnya.

\section{B. Metode Pengumpulan Data}

Metode yang digunakan dalam rancangan karya ini adalah metode kualitatif yaitu observasi, wawancara, metode pengamatan langsung yang di dasarkan atas pengalaman yang dialami secara langsung serta mengumpulkan data melalui internet.

Metode wawancara memerlukan percakapan dengan maksdu tertentu yang dilakukan oleh dua pihak yaitu pewawancara (interviewer) yang mengajukan pertanyaan dan yang di wawancarai (interviewe) yang memberikan jawaban atas pertanyaan itu. Maksud dari mengadakan wawancara antara lain untuk mengumpulkan informasi mengenai orang, kejadian organisasi, perasaan, motivasi, tuntutan, kepedulian dan lain-lain. Metode wawancara penulis gunakan untuk mengumpulkan data secara mendalam yang dilakukakan secara formal dan non formal terhadap pemilik Toko Teri Bajak Medan.

Hasil data yang di peroleh kemudian akan diolah dan dianalisa sehingga menemukan titik temu tentang identitas yang akan dimunculkan sehingga pencitraan Toko Teri Bajak Medan dapat dihadirkan.

Sedangkan metode yang digunakan dalam menganalisis data adalah SWOT dimana menganalisis data perusahaan terhadap saingan diolah menggunakan metode SWOT. Metode ini dapat mengungkap kekuatan, kelemahan, kesempatan, dan ancaman yang dimiliki perusahaan jika dibandingkan dengan perusahaan saingan dan target audience akan terus ditanya tentang motif melakukan suatu tindakan hingga dapat diketahui motif murninya. 


\section{Data Perusahaan}

Perusahaan yang dijadikan objek perancangan ini adalah home industry teri bajak yang berlokasi di Jalan Balai Kota No. 1 Medan. Toko ini berdiri pada tahun 2013.

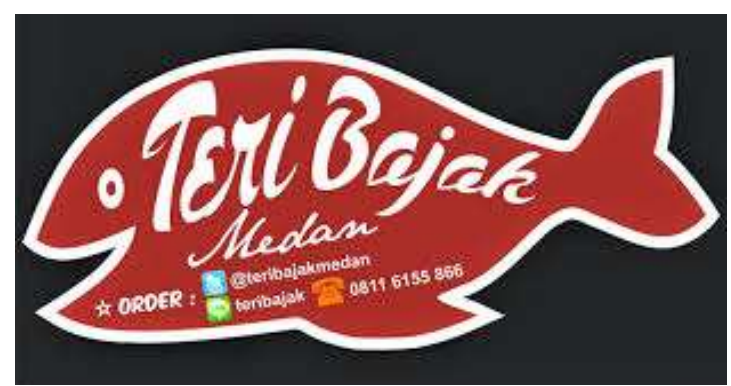

Gambar 1. Logo Teri Bajak

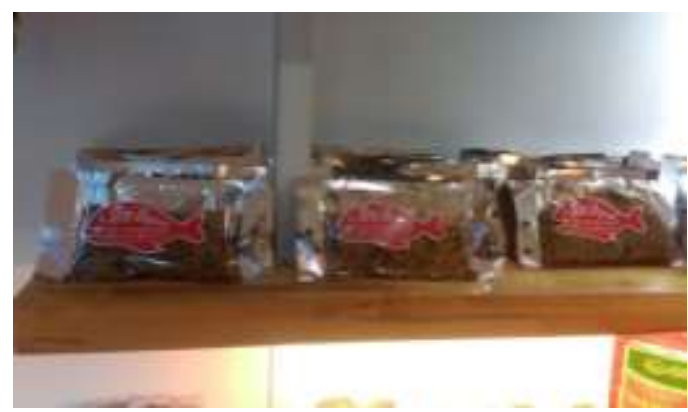

Gambar 2. Produk Teri Bajak

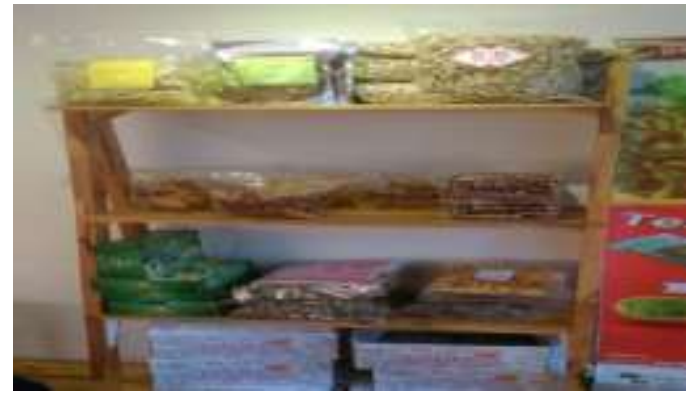

Gambar 3. Produk Teri Bajak

Home industry toko teri bajak ini dikelola oleh Windi Septia Dewi, peluang usaha kuliner teri yang berhiaskan bumbu sambal menggugah selera lalu dikemas apik. Bisnis perempuan kelahiran 29 September 1991 ini dinamainya Teri Bajak Medan yang dibukanya sejak 17 Juni 2013.

Penambahan kata Bajak di tengah, sebenarnya diilhami dari lokasi makanan ini diproduksi. Di Medan, ada sebuah lokasi di kawasan Kecamatan Medan Amplas, di mana nama Jalannya dihiasi dengan kata Bajak. Windi dan keluarganya sendiri tinggal di Bajak V. "Awalnya banyak nama-nama yang jadi kandidat. Tapi karena banyaknya jadi bingung. Nama yang kepikiran ribet semua, sampai saat jalan pulang ke rumah masih sambil mikir. Terbaca alamat rumah Jalan Bajak V. Akhirnya jadi TERI BAJAK. Dan sekarang arti dari Teri Bajak itu sendiri sudah menjadi Slogan 'Teri Bajak siap membajak lidah Anda' karena berharap Teri Bajak bisa dikenal hingga ke seluruh kota di Indonesia bahkan dieskpor. Jadi walaupun bisnisnya ikan teri tetapi bisnisnya bisa kelas kakap". 


\section{Dasar Teori}

Perancangan adalah tahapan perancangan (design) memiliki tujuan untuk mendesain sistem baru yang dapat menyelesaikan masalah-masalah yang dihadapi perusahaan yang diperoleh dari pemilihan alternative sistem yang terbaik. (Ladjamudin, 2005:39).

Logo adalah sebuah merek atau brand. Sebuah desain logo merupakan perwakilan sebuah perusahaan. Desain logo perusahaan adalah pembeda visual suatu perusahaan dengan perusahaan lain. Didalam desain logo yang bagus, akan terlihat filosofi, visi dan misi dari perusahaan tersebut.

Berdasarkan hal tersebut penulis menyimpulkan perancangan logo yaitu sebuah proses perencanaan merek atau brand dengan berlandaskan konsep dan data yang ada kemudian disatukan menjadi sebuah solusi dan dapat memecahkan masalah yang ada.

Biasanya, identitas suatu unit usaha atau organisasi komersial akan selalu hadir dalam komponen-komponen sebagai berikut :

- Produk (barang atau jasa) yang dihasilkan. Bergerak dalam usaha apa dan jenis produk apa yang dihasilkan.

- Tempat/Lokasi. Bagaimana situasi pabrik, workshopnya dan gedungnya.

- Komunikasi. Bagaimana komunikasi yang dilakukan (Promosi, Advertising sampai pada logo dan brand yang di pakai), atribut sampai seragam yang digunakan perusahaan.

- Branding adalah nama, istilah, tanda, simbol, atau rancangan, atau kombinasi dari semuanya, yang dimaksudkan untuk mengidentifikasikan barang atau jasa atau kelompok penjual dan untuk mendiferensiasikannya (membedakan) dari barang atau jasa pesaing (Kotler, 2009:332).

- Bagi sebuah perusahaan, branding tidak sekadar berfungsi sebagai corporate identity, tetapi dapat meningkatkan brand image (Citra yang terbentuk dalam benak konsumen mengenai sebuah merk tertentu) yang luar biasa, jika digarap dengan profesional.

- Branding berarti suatu pernyataan mengenai siapa (identitas), apa yang dilakukan (produk/jasa yang ditawarkan), dan mengenai kenapa suatu merek layak dipilih (keistimewaan). Brand adalah reputasi, merek yang memiliki reputasi adalah merek yang menjanjikan, sehingga publik mempercayai dan memilih merek tersebut (Neumeier, 2003:54).

Fungsi Branding adalah untuk menanamkan image dan citranya di masyarakat bahkan konsumennya, jika perusahaan tersebut memiliki produk yang mereka jual, sehingga dengan adanya branding (merk dagang atau corporate identity) diharapkan brand atau merk mereka akan senantiasa diingat oleh masyarakat atau konsumennya dalam jangka waktu yang lama.Terdapat tiga tujuan dalam membangun brand, yaitu: membentuk persepsi, membangun kepercayaan dan membangun cinta (kepada brand) (Neumeier, 2003:41).

\section{STUDI LITERATUR}

Dalam penulisan karya ilmiah ini, penulis banyak membaca dan mengamati jurnal, tesis dan bahan kajian yang bisa dijadikan sumber bacaan bagi penulis, beberapa bahan bacaan yang penulis jadikan sumber yaitu jurnal Universitas Kristen Petra, yang berjudul "Perancangan Rebranding Sepatu Bayi Rier Untuk Pasar Ekonomi Kelas Menengah" dan tesis Institut Seni Indonesia Padangpanjang yang berjudul "Brand Indentity Biro Travel Padang Tour Wisata Pulau", dimana dalam penulisan karya ilmiah ini penulis sangat terbantu dalam hal pengkonsepan karya dan penulisan karya.

\section{PEMBAHASAN}

Dari segi logo pada teri bajak medan baik dari logotype dan logogram sangat kurang mewakili kota asal makanan ini berasal. Padahal dari segi produk, teri bajak tidak sama 
seperti kompetitornya yaitu produk kue yang seharusnya tidak menjadi kendala yang mutlak bagi perkembangan teri bajak karena produk yang ditawarkan tidak ada yang sama dengan produk teri bajak, tetapi dengan maraknya public figure membuka gerai toko oleh-oleh yang beredar di berbagai daerah membuat daya saing teri bajak semakin ketat, sehingga mempengaruhi pendapatan teri bajak.

Dari segi harga, teri bajak termasuk cukup kompetitif, dapat bersaing di pasaran. Hanya saja hal itu membuat keuntungan menjadi makin tipis. Dengan harga yang relatif sama, biaya produksi yang dikeluarkan teri bajak lebih besar dari pesaing. Hal ini sangat berbahaya untuk perkembangan jangka panjang. Dengan semakin kecilnya keuntungan, maka perusahaan akan makin sulit berkembang.

Permasalahan lain datang dari segi promosi. Tidak ada promosi menarik yang bisa dibuat seperti layaknya public figure dalam mempromosikan produknya, karena teri bajak sendiri tidak mempunyai value lebih yang dapat ditawarkan kepada target audience. Jadi kesimpulan masalah dari teri bajak adalah kurangnya value dalam brand yang dapat mempengaruhi target audience untuk berkunjung ke teri bajak.

Tabel 1. Analisa SWOT

\begin{tabular}{|l|l|}
\hline $\begin{array}{l}\text { Strength } \\
\text { (Kekuatan) }\end{array}$ & $\begin{array}{l}\text { Weaknes } \\
\text { (Kelemahan) }\end{array}$ \\
\hline $\begin{array}{l}\text { 1) Murah Terdapat banyak } \\
\text { produk yang di } \\
\text { tawarkan Desain Kemasan } \\
\text { 3) Dapat } \\
\text { menerapkan sistem } \\
\text { pembelian online } \\
\text { bagi konsumen }\end{array}$ & $\begin{array}{l}\text { 2) Tidak ada identitas } \\
\text { yang jelas }\end{array}$ \\
\hline $\begin{array}{l}\text { Oppotunities } \\
\text { Peluang) }\end{array}$ & Threats (Ancaman) \\
\hline $\begin{array}{l}\text { 1) Produk yang } \\
\text { ditawarkan berbeda } \\
\text { dengan Pendapatan semakin } \\
\text { kompetitornya }\end{array}$ & $\begin{array}{l}\text { rendah jika promosi } \\
\text { tidak dilakukan sebaik } \\
\text { mungkin }\end{array}$ \\
\end{tabular}

Dari analisa tersebut dapat ditarik kesimpulan masih banyaknya kekurangan yang harus perbaiki salah satunya tidak memiliki identitas yang jelas dalam produknya.

\section{A. Rancangan Konsep Rebranding}

Unsur-unsur yang terdapat pada garapan Rebranding logo Teri Bajak Medan, penentuan Tagline dan mengaplikasikan ke dalam media yang di anggap efektif dan efesien dalam membangun sebuah logo. Adapun strategi yang digunakan dalam rancangan ini adalah merancang dengan menggunakan perpaduan warna yang memberikan gambaran masyarakat sumatera utara. Konsep rancangan Rebranding logo Teri Bajak yang muncul adalah melalui konsep verbal dan konsep visual. Konsep verbal rebranding logo teri bajak menggunakan kata-kata yang simple namun memberikan kesan yang bermakna sehingga image yang di harapkan dapat sampai kepada target audience.

Sementara kata-kata (Tagline) yang digunakan adalah mampu mewaikili Teri Bajak secara keseluruhan, sehingga simple nya sebuah desain dan keindahan estetika sebuah desain dapat terjaga dengan baik. Adapun konsep visual yang akan di munculkan adalah visualisasi 
dalam berbagai unsur dan elemen seperti warna dan tipografi. Visualisasi di gabungkan sehingga semua warna yang di pakai pada rancangan adalah warna yang mendukung tema rancangan. Terdapat beberapa unsur yaitu warna merah dan kuning yang menggambarkan suku khas masyarakat sumatera utara yaitu Batak dan Melayu. Warna merah menggambarkan masyarakat Batak sedangkan warna kuning menggambarkan masyarakat Melayu, adapun filosofi warna merah yaitu berani, perayaan, kekayaan, nasib baik, suci, tulus, gairah, kuat, energi, api, cinta, roman, gembira, cepat, ambisi, pemimpin, maskulin, tenaga, bahaya, menonjol, darah, revolusi, radikal, sosialisme, agresi sedangkan warna kuning lambang kejayaan, cita-cita yang luhur, sinar matahari, gembira, bahagia, tanah, optimis, cerdas, idealisme, kaya (emas).

Adapun visual yang ditampilkan mengarah pada penonjolan identitas Teri Bajak. Sedangkan untuk gaya desain lebih bersifat aktif, dinamis tetapi tetap ada kesan menarik.Perancangan rebranding logo bertujuan untuk menarik value target audience serta medekatkan diri kepada konsumen sedangkan target audience adalah masyarakat sumatera utara khusunya kota medan sendiri dan para wisatawan luar yang berkunjung ke kota medan.

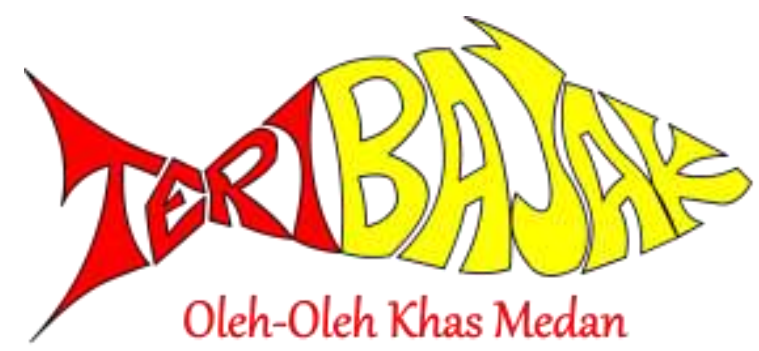

Gambar 4. Logo baru Teri Bajak

Logo terbaru teri bajak ini memberikan kesan elegan, simpel dan tidak ribet, penggabungan logotype dan logogram yang diterapkan dalam perancangan rebranding teri bajak memberikan nuansa yang baru bagi keberadaan teri bajak, pemberian warna merah dan kuning mampu mewakili karakter dan identitas teri bajak tersebut.

\section{B. Pengaplikasian Logo}

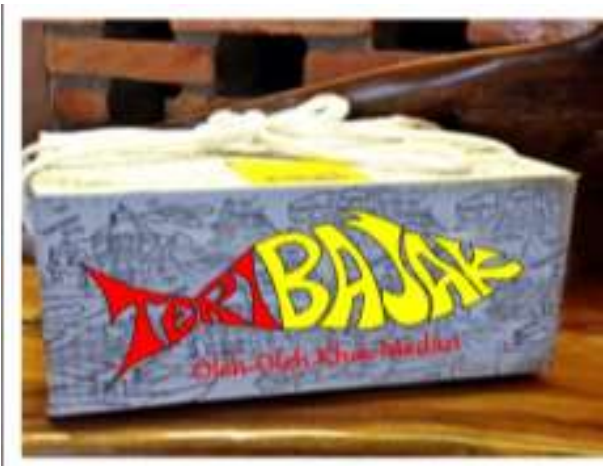

Gambar 5. Box Teri Bajak 


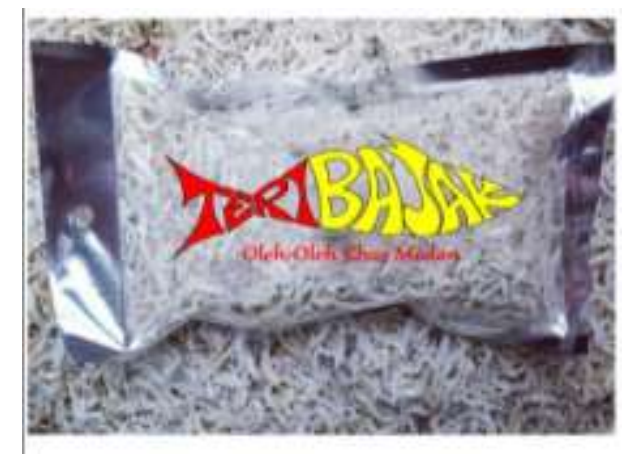

Gambar 6. Kemasan Plastik Teri Bajak

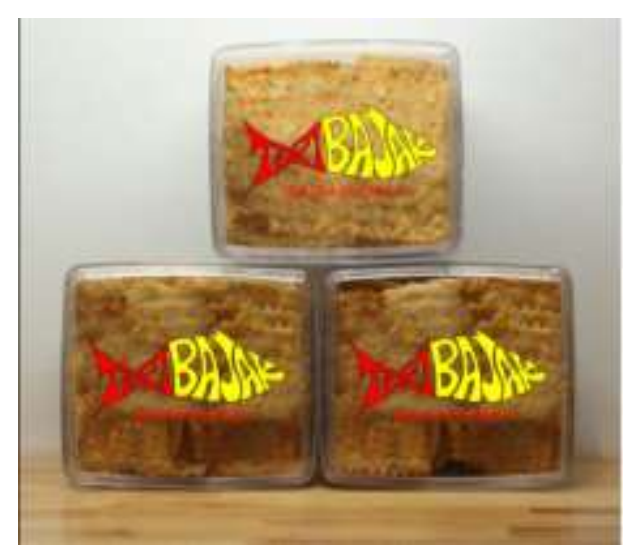

Gambar 7. Kemasan Teri Bajak

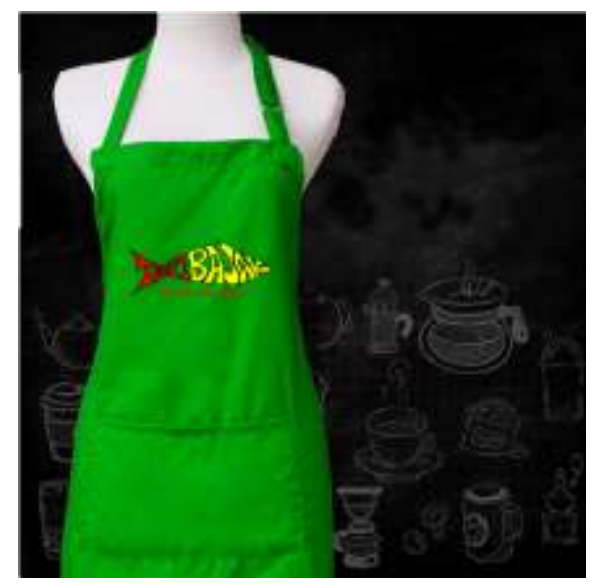

Gambar 8. Celemek Pelayan 


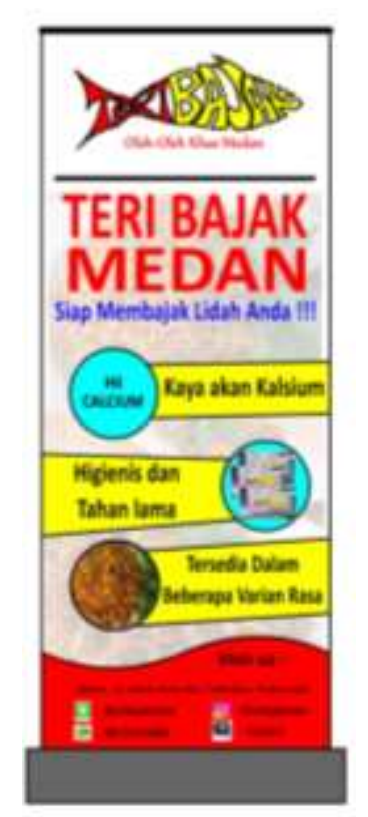

Gambar 9. Banner Teri Bajak

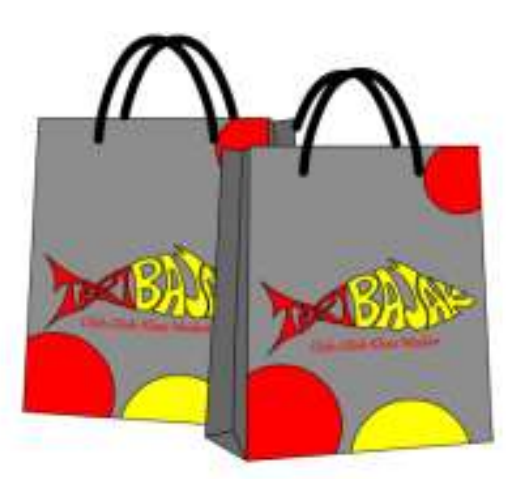

Gambar 10. Paperbag Teri Bajak

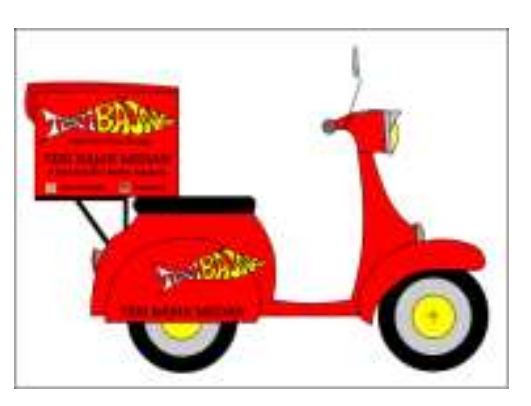

Gambar 11. Delivery Motor Teri Bajak 


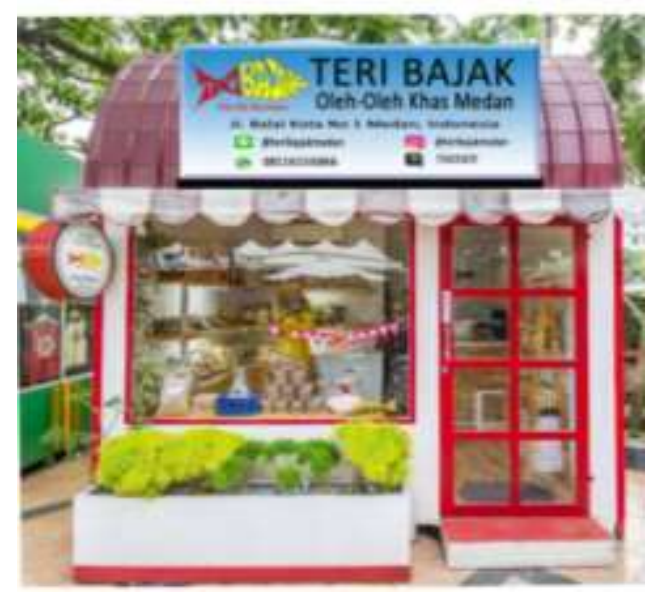

Gambar 12. Plank merk Teri Bajak

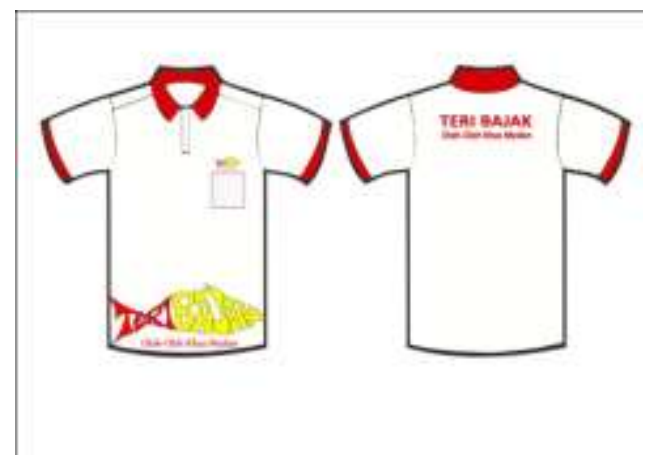

Gambar 13. Baju Karyawan Teri Bajak

Dengan pengaplikasian pada media tersebut sehingga mampu mengenalkan kembali brand teri bajak pada target audience. Mengenalkan produk teri bajak sebagai produk oleh-oleh dengan cara mendesain kemasan hingga mempunyai kesan tersendiri. Promosi dilakukan di sosial media sebagai bentuk pemasaran dan banyaknya wisatawan mendapatkan informasi melalui sosial media. Dengan berkembangnya zaman semoga dapat menambah jumlah varian seiring dengan berkembangnya perusahaan sesuai dengan kebutuhan dan permintaan konsumen. Membuat varian tematik, sesuai dengan berbagai perayaan atau event besar di Indonesia

\section{PENUTUP}

Struktur perancangan rebranding logo teri bajak menggambarkan masyarakat dominan yang ada di sumatera utara yaitu Batak dan Melayu dimana diimplementasikan dengan warna merah yang mencirikan suku batak dan kuning yang mencirikan suku melayu.

Adapun filosofi warna merah yaitu berani, perayaan, kekayaan, nasib baik, suci, tulus, gairah, kuat, energi, api, cinta, roman, gembira, cepat, ambisi, pemimpin, maskulin, tenaga, bahaya, menonjol, darah, revolusi, radikal, sosialisme, agresi sedangkan warna kuning lambang kejayaan, cita-cita yang luhur, sinar matahari, gembira, bahagia, tanah, optimis, cerdas, idealisme, kaya (emas). Visual yang ditampilkan mengarah pada penonjolan identitas Teri Bajak. Sedangkan untuk gaya desain lebih bersifat aktif, dinamis tetapi tetap ada kesan menarik. 


\section{DAFTAR PUSTAKA}

[1] Susanto, A., Wijarnoko, H. (2004). Power Branding: Membangun Merk Unggul dan Organisasi Pendukungnya. Jakarta: Mizan Pustaka.

[2] Kusrianto, Adi. (2006). Pengantar Desain Komunikasi Visual. Surabaya: Andi.

[3] Sarwono, Jonathan \& Lubis, Hari. (2007). Metode Riset untuk Desain Komunikasi Visual. Bandung: Andi Offset.

[4] Simamora, B. (2002). Aura Merk:7 Langkah Membangun Merek Yang Kuat.Jakarta: Gramedia Pustaka Utama.

[5] Rustan, S. (2011). Font \& Tipografi. Jakarta: Gramedia Pustaka Utama.

[6] Suyanto, M. (2004). Aplikasi Desain Grafis untuk Periklanan Dilengkapi Sampel Iklan Terbaik Kelas Dunia. Yogyakarta: Andi. 